\title{
Savigny and the Lex Fori, Story and Jurisdiction: A Reply to Professor Briggs
}

\author{
Albert A. Ehrenzweig*
}

M OST AUTHORS would be happy to see their work deemed worthy of as detailed and learned an attack as Edwin W. Briggs' analysis of my Treatise in the November 1964 issue of the U.C.L.A. Law Review. ${ }^{1}$ I am indeed grateful for that analysis despite its subtitle which accuses my approach of falling short of "law and reason" and despite much of the author's harsh language which contrasts so sharply with his many friendly evaluations of my effort.

Professor Briggs has set forth his "institutional approach" in a long series of articles and it would be presumptuous if in this reply I were to take issue with the substance of his teaching. Nor shall I undertake here to defend my own views. I have recently attempted to do this in connection with the Conflict of Laws roundtable of the Association of American Law Schools devoted to this topic. ${ }^{2}$

All I shall try to do in this brief comment is to counter the reasoning which Briggs claims to have caused his "inability to accept ... [my] handling of historical materials, and ... [my] interpretation of cases, ${ }^{3}$ and his lacking confidence" in many of my conclusions. ${ }^{4}$ That reasoning relates to my treatment of "scholarly writings" as represented by Savigny and of the early case law rehed on by Story for his theory of jurisdiction which Briggs considers to be based on "common law due process."

"SCHOLARLY WRITINGS": SAVIGNY'S THEORY

Professor Briggs finds "substantial cause for doubting ... [my] use of source materials" in what he considers my "misinterpretation" of Savigny. ${ }^{5}$ From the latter's rejection of the vested rights doctrine I have concluded that he "denied to any foreign law a right to apphication, and

* Dr. Jur., 1928, Vienna, Austria; J. D., 1941 University of Chicago; LL.M., 1942, J.S.D., 1952, Columbia University; Professor of Law, University of California, Berkeley; Honorarprofessor of Conflict of Laws, University of Vienna.

${ }^{1}$ Briggs, An Institutional Approach to Conflict of Laws: "Law and Reason" versus Professor Ehrenzweig, 12 U.C.L.A.L. Rev. 29 (1964).

2 A Proper Law in a Proper Forum: A "Restatement," in Symposium on "Ehrenzweig's Proper Forntm and Proper Law," 18 OkLA. L. REv. No. 2 (1965) (forthcoming), with bibliography.

3 Briggs, supra note 1 , at 41 n.52.

4 Id. at 47 .

Id. at 39 . 
thus recognized the lex fori as the fountainhead of all conflicts law." This conclusion Briggs considers as unjustified because "Savigny is very certain that there is a developing body of 'universal customary law' ... . [and] is expressing a growing consensus as to the 'seat of the legal relationships in each case." "7 Both of these observations I have made myself. I have noted both Savigny's "great contribution" to doctrine which he made in "his theory of the 'seat of the legal relation," and his likely responsibility "for the internationalist illusion of his successors," which I found in his assumption of an "international common law of nations." Of course, this approach caused Savigny, as Briggs correctly states, to repudiate the municipal law of the forum as the rule to be generally applied by the judge. ${ }^{\circ}$ But, contrary to Briggs' assumption, this repudiation did not prevent Savigny from recognizing the lex fori as "the fountainhead of all conflicts law," as I have suggested. ${ }^{10}$ For to Savigny application of foreign law occurs merely owing to a voluntary "admission of originally foreign laws among the sources from which the forum must derive the decision of certain legal relations." for international relations the existence of a super-law that might exist for the solutions of interstate conflicts. ${ }^{12}$

\section{II}

\section{CASE LAW: STORY'S "JURISDICTION"}

His "inability to accept [my] interpretation"13 of court decisions-in the almost ten thousand cases which underhe my Treatise-Professor Briggs explains mainly, if not solely, by the examination of a case to which I briefly referred in a footnote to what he has branded as my "distorted" discussion of Story's theory of jurisdiction. ${ }^{14}$ That examination,

6 Eirenzweic, Conflict of Laws 322 (1962) (emphasis added) (hereinafter referred to as Treatise). Briggs quotes erroneously ". . . conflicting laws."

7 Briggs, supra note 1 , at 39,40 .

8 TREATISE 322.

9 Much of Professor Briggs' criticism of my views is probably due to his assumption that a conflicts theory treating the laws of the forum as basic or residuary, postulates that law as being "always the basic choice." Briggs, supra note 1 , at 32 .

${ }^{10}$ See supra note 6 and accompanying text.

118 Savigny, System des heutigen römaschen Privatrechts 28 (1849). Briggs, in his attack on my "misinterpretation" of Savigny does not consider that passage. It is important because Savigny's shift from the statutist distinction of types of conflicting laws to an analysis of legal relations is crucial. See Keged, Internationales Prryatrecht 65 (2d ed. 1964).

12 Savigny, A Treatise GN tere Conflict of Laws 71 (Guthrie trans. 2d ed. 1880). Professor Briggs fails to note this passage although I have rebed on it for my thesis. It is regrettable that both of us have used Gutbrie's hardly comprehensible translation.

${ }^{13}$ See note 3 supra and accompanying text.

14 Briggs, supra note 1 , at 40,41 . 
however, though correctly drawing attention to an error in my statement of the case, does not affect the substance of my argument.

In Kibbe v. Kibbe, ${ }^{15}$ the Connecticut court had refused recognition of a Massachusetts judgment on the ground that Massachusetts "had no legal jurisdiction of the cause." I have suggested that this concept, so strongly relied on by Story, of a "legal" jurisdiction measured by a law other than that of the rendering court "was far from generally accepted."16 This I concluded in part from Judge Sewall's opinion in Bissell v. Briggs, ${ }^{17}$ who, subsequently, in a Massacluusetts suit on a New Hampshire judgment, would apparently have limited his inquiry to an examination of "the manner in whicl a particular jurisdiction is exercised, according to its own regulations and laws of the state from whence an authenticated judgment is taken."18 Now I gladly açknowledge that I took this quotation from the opinion of one of three judges without noting that that judge did not agree with the majority of the court. This I should have noted and mentioned notwithstanding that Judge Sewall's opinion was not designated as a "dissent" in the modern American fashion. ${ }^{19}$ But, even if I had not committed the error of calling his opinion that of the court, I would have used his language to support my thesis.

All I claimed was that the Kibbe ruling "was far from generally accepted." And this appears, I beheve, rather clearly from the fact that twenty-five years later a judge on the Supreme Judicial Court of the Commonwealth of Massachusetts could argue that a court's jurisdiction to entitle its judgment to full faith and credit in sister states was "conclusively proved by the judgment." ${ }^{20}$ For "if full faith and credit mean anything, one would suppose the judgments certified from Massacliusetts to have been entitled to credit for the jurisdiction of the court in which they were rendered; that is that their authority had been duly exercised according to the laws and usages of Massachusetts. . . ."21 True, the other judges disagreed and declared it "unreasonable to oblige any man living in one state, and having effects in another state, to make himself amenable to the courts of the last state; ${ }^{\prime 22}$ true, also, that in Kibbe v. Kibbe $e^{23}$ and Phelps v. Holker, ${ }^{24}$ the Connecticut and Pennsylvania courts had applied

15 Kibbe v. Kibbe, Kirby 119 (Conn. 1786).

16 Treatise 8 n.6.

17 Bissell v. Briggs, 9 Mass. 461 (1813).

18 Id. at 477 . (Empbasis added).

${ }^{10}$ See generally Nadelmann, The Judicial Dissent, 8 Axr. J. Coxr. L. 415, 418-19 (1959).

20 Bissell v. Briggs, 9 Mass. 461, 477 (1813).

21 Id. at 473.

22 Id. at 468.

23 Kirby 119 (Conn. 1786).

24 Phelps v. Holker, 1 Dall. (1 U.S.) 261 (Pa. 1788). Briggs (supra note 1 , at 42), main- 
something that Briggs calls "common law due process" standards in denying a sister state's jurisdiction. But all of this I have conceded and merely maintained that those standards were "not generally accepted" at Story's time. And this, I believe, remains true in the light of Judge Sewall's opinion, and of those other arguments I have submitted to support my contention.

Professor Briggs' final objection in this context concerns my alleged assertion that "mere service of process on a transient was never recognized as a sufficient basis in itself of the exercise of personal jurisdiction over him." ${ }^{25}$ This I have never said. Rather, I have expressly referred to two typical situations in which American courts have in fact held transient service generally sufficient as such. ${ }^{26}$ One of these situations I have identified as that where "the cause of action had arisen within the state and was thus subject to domestic law."27 I plead guilty to having misplaced a footnote digit and thus made Bissell v. Briggs ${ }^{28}$ appear to support this proposition, instead of citing that case in support of that other typical situation in which "the plaintiff was entitled to the protection of the forum and his interest in speedy justice was deemed to outweigh the transient defendant's preference for his own forum."20 But this typographical error has, of course, not induced me to make the assertion ascribed to ine by Professor Briggs. Nor have I been able to find in another case with whose "misconstruction" I have been charged, ${ }^{30}$ those passages in which "the Pennsylvania court repeatedly takes it for granted that in any case in which the defendant is served personally in the forum the court very properly acquires personal jurisdiction."31

Neither that case nor Bissell $v$. Briggs thus stands for a general rule of transient jurisdiction, and I still consider the "power" rationale of that jurisdiction as a myth. But be that as it may, be it even that Professor Briggs' interpretation of Savigny is preferable to mine, I do not believe that my interpretations of legal history would be of "utmost importance" in [my] attempt to provide a plausible rationale for [my] thesis-"lex fori-basic rule." ${ }^{32}$ For iny thesis was and is merely that the interpretation

tains that the Court in that case used "the essence" of jurisclictional language. Be this as it may, it did not use such language. And this is all that I have said.

25 Briggs, supra note 1 , at 45 .

26 Treatise 106.

27 Ibid.

28 Bissell v. Briggs, 9 Mass. 461 (1813).

29 Treatise 106.

30 Coleman's Appeal, 75 Pa. 441 (1874).

31 Briggs, supra note 1 , at 46.

32 Id. at 47. 
of the domestic rule of the forum must fill such gaps as are left by the "true" conflicts rules of American conflicts law; and that thesis has nothing to do with either Savigny's attitude to the law of the forum or Story's theory of jurisdiction. ${ }^{33}$

33 Briggs uses certain quotes, unintentionally, $I$ am sure, which impute to me statements such as that I have "once and for all" proved the falseness of legislative jurisdictional principles (33) ; or that every court is "'free as the wind" to resolve all questions of choice of law" (34); or that I have "demolished" orthodox theory (35). I have, of course, never claimed that every "court is completely free and competent to determine 'choice of law' just as it sees fit" (33) but repeatedly stressed the binding character of all "true rules" of choice. See Treatise 353-54; see also Eerenzweig, Conflicts in a Nutsheli $\$$ (1965). 